\title{
ENGINEERING-GEOLOGICAL MAPS OF GEOLOGICAL FACTORS OF THE ENVIRONMENT IN SLOVAKIA
}

\author{
FRANTIŠEK BALIAK, MARTIN BRČEK \\ Slovak University of Technology in Bratislava, Faculty of Civil Engineering, \\ Radlinského 11, 81368 Bratislava, Slovakia. \\ E-mail: frantisek.baliak@stuba.sk,martin.brcek@stuba.sk
}

\begin{abstract}
In recent years, we have witnessed very frequent natural disasters such as earthquakes, floods, landslides, storms and similar. In most cases, disasters are caused by geological factors, especially geobarriers. Geobarriers threaten the life and works of man or reduce the effectiveness of the construction and operation of technical works, or harm the environment by negative anthropogenic influences. An important task in assessing the technical and environmental aspects of particular engineering activity is to assess the impact of constructions on the production and protection of the environment. The important part of the environment is the geological environment. In this paper, we give an overview of geological factors of the environment and the way how they are illustrated in the engineering-geological maps made in Slovakia.
\end{abstract}

\section{INTRODUCTION}

All engineering activities (including mineral processing) in the natural environment have to be considered in the context of their impact (positive or negative) on the environment. An inseparable part of the environment is geological environment with various specifications.

Activities promoting territorial development of different countries are affected to a basic extent by geological conditions. Due to the growing development particular approach must be emphasized in providing harmonic incorporation of engineering works within the natural-geological environment, as well as in maximum reduction of negative impacts of construction on the environment.

Various geological factors influence either directly or indirectly the environment in positive (geopotentials) or negative (geobarriers) sense.

An overview of geological factors of the environment and the way how they are illustrated in the engineering-geological maps made in Slovakia are presented.

\section{GEOLOGICAL FACTORS (GEOFACTORS) OF THE ENVIRONMENT}

\subsection{BASIC TERMS}

Environment - consists of natural conditions required for existence of organisms including human beings, for their further development. Its components are atmosphere, water, soil, organisms, ecosystems and energy (acc. to [1]). 
Geological environment - part of the lithosphere which directly influences the conditions of the existence and development of the society which man exploits and converts.

Geological factors of the environment - components of the geological environment and occurring processes, influencing the way of utilization of the geological and landscape environment [4].

Engineering-geological maps of environmental geofactors - special type of extrapolated maps, demonstrating those natural-geological and anthropogenic phenomena which significantly influence the rational and optimum utilization of the landscape and environmental protection.

\subsection{REVIEW OF GEOFACTORS}

Geofactors which make it possible to use the territory to a certain extent are called geopotentials. Geofactors jeopardizing the landscape and environment, or preventing its utilization are called geobarriers [6].

As geopotentials there are considered various natural resources and potentialities available for the favourable development of the society. Among geofactors of this group not only the traditional raw materials and groundwaters are included, but also arable fertile soils, good foundation soils, and construction materials, which encouraged the development of human civilization process since earliest times. At present, also potentials of the geological environment creating, for instance, suitable conditions for wastes disposal are of great importance and are appreciated.

Geobarriers are various obstacles and limitations of geological character, influencing or completely preventing utilization of the nature for favourable development of the society [7].

These barrier effects, sometimes very difficult to overcome, may be caused by:

- geological factors jeopardizing human lives and their engineering works,

- geofactors causing unfavourable interactions between the geologic environment and engineering works, thus significantly decreasing their efficiency, serviceability, and operation safety,

- geofactors representing retroactive negative impacts of engineering works and interventions, damaging the geological and natural environment and requiring its protection and revitalization.

\section{ENGINEERING-GEOLOGICAL MAPS OF ENVIRONMENTAL GEOFACTORS}

Engineering-geological maps of environmental geofactors are a special type of maps demonstrating those natural-geological and antropogenous phenomena which 
significantly influence the rational and optimum utilization of the landscape and environmental protection.

Drawing up of those maps was based on the general knowledge of multicriterial basic maps of engineering-geological conditions, representing the character of respective basic components of the engineering-geological evaluation, in which these components are synthetically evaluated and territorial units of equal engineeringgeological character are separated.

In Slovakia, the map of engineering-geological zoning is a part of the set of engineering-geological maps of geological factors of the environment at a scale of 1:50.000 [3].

In addition to this map, the set includes the following types of maps:

- relevant geological factors map,

- landslide susceptibility map,

- map of the susceptibility of the area to collapsibility of soils,

- additional maps according to requirements and regional specific characteristic of the area.

\subsection{RELEVANT GEOLOGICAL FACTORS MAP}

The map of significant geological factors of the environment is a multipurpose synthetic map presenting from the engineering-geological point of view a complex image of all relevant geological factors of the environment of respective area.

The map presents geological factors of the environment:

1. Geofactors supporting favourable society development
a) mineral deposits,
b) groundwater resources,
c) good quality agricultural soils,
d) good quality foundation soils,
e) suitable areas for waste disposal and landfills.

2. Geofactors jeopardizing life and human activities
a) earthquakes,
b) disastrous slope failures,
c) inundation, flooding of areas adjacent to rivers,
d) toxic, radiation and other hazards jeopardizing health of population.

3. Geofactors decreasing efficiency of construction and operation of engineering works
a) foundation soils with high compressibility and low bearing capacity,
b) slopes with low stability,
c) high groundwater level and waterlogged foundation soil,
d) corrosive groundwater,
e) seismic areas. 
4. Geofactors deteriorating the environment due to negative antropogenous activity

a) subsidence of the territory due to underground mining,

b) devastation of the area due to surface mining and waste dumps,

c) graphic symbols in the map of geofactors draw attention to the sources and extent of groundwater and soil contamination, due to unsuitable waste disposal, agricultural activity and industrial production.

The map presents also the protected areas (national parks, state nature reserves, protected landscape regions; Fig. 1).



Fig. 1. Map of significant geological factors [8]

\subsection{LANDSLIDE SUSCEPTIBILITY MAP}

The map of relative susceptibility to slope movements is a separate map of engineering-geological zoning. It presents evaluation of the territory with regard to slope stability, specifying zones and sub-zones with equal or similar susceptibility to the development of slope deformations. The methodology of the map elaboration is based on the empirical evaluation of the factors of slope deformation origin and development. 
The territories are classified in three zones:

a) the zone of unstable areas,

b) the zone of potentially unstable areas,

c) the zone of stable areas.

The zone of unstable areas includes areas with more extensive occurrence of slope deformations accompanied by unfavourable geological conditions.

The zone of potentially unstable areas includes those territories where either one main criterion (slope deformations or unfavourable geological conditions) or eventually some secondary criteria (morphological, hydrogeological or vegetation conditions) occur. Slope deformations are not very frequent; however, they cannot be completely eliminated.

The origin and activization of slope deformations due to natural impacts may not be assumed in the zone of stable areas.

The map is provided with the list of designations - symbols, with a characteristic of zones and sub-zones. The text presents significant information for built-up areas.

\subsection{MAP OF SUSCEPTIBILITY OF THE TERRITORY TO COLLAPSIBILITY OF SOILS}

It is necessary to elaborate the above mentioned maps for territories where collapse sediments cause serious problems with regard to construction. The most susceptible to collapsing are eolian sediments with low natural moisture, high silt content, and high occurrence of pores, with the size of about $0.01 \mathrm{~mm}$, situated in the area of watershed divides or higher terraces.

On the basis of the criteria mentioned the territory of the Slovak Republic is divided according to homogeneity and with regard to collapsibility into the following zones:

a) territories with soils unsusceptible to collapsing,

b) territories with soils moderately susceptible to collapsing,

c) territories with soils susceptible to collapsing,

d) territories with soils predisposed to collapsing.

\subsection{OTHER ENGINEERING GEOLOGICAL MAPS OF GEOFACTORS}

In addition to the maps mentioned above, there are other engineering geological maps of the territory of Slovakia containing information about groundwater, seismicity, slope failures, etc.

In this category, the following types of maps can be included:

- hydrogeological maps,

- land suitability for waste disposal maps,

- toxic and radiation hazard maps,

- slope failure maps and other (Fig. 2).

The scale of individual maps depends on the level of importance and varies from 1:5000 to $1: 50000$ (Fig. 3). 


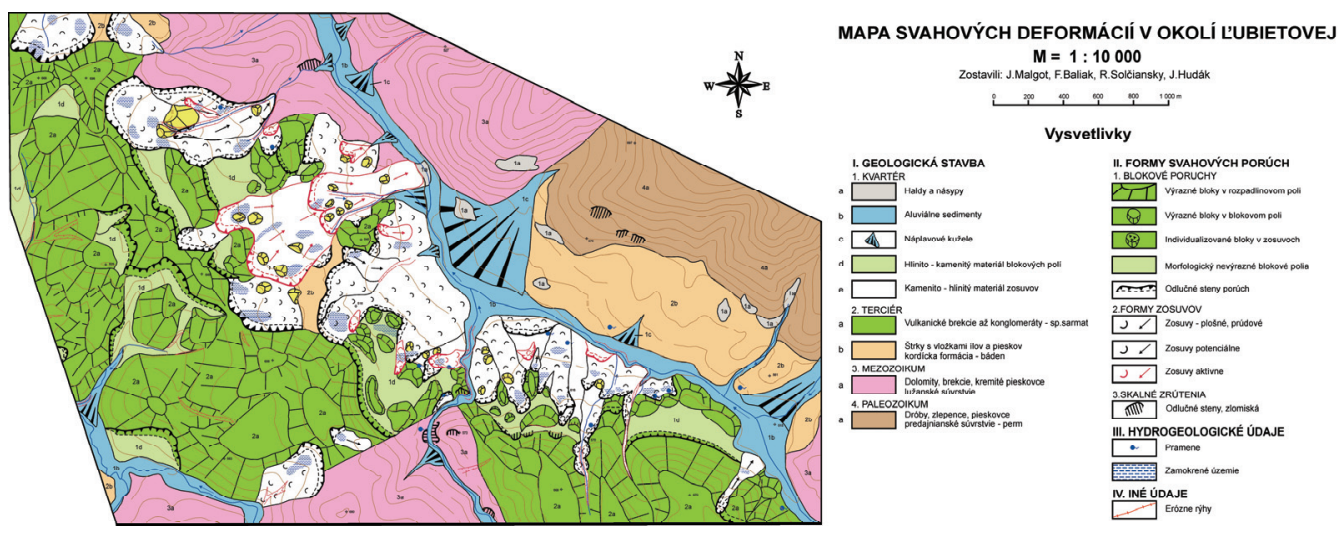

Fig. 2. Part of the map slope failures in the vicinity of Lubietová village [2]

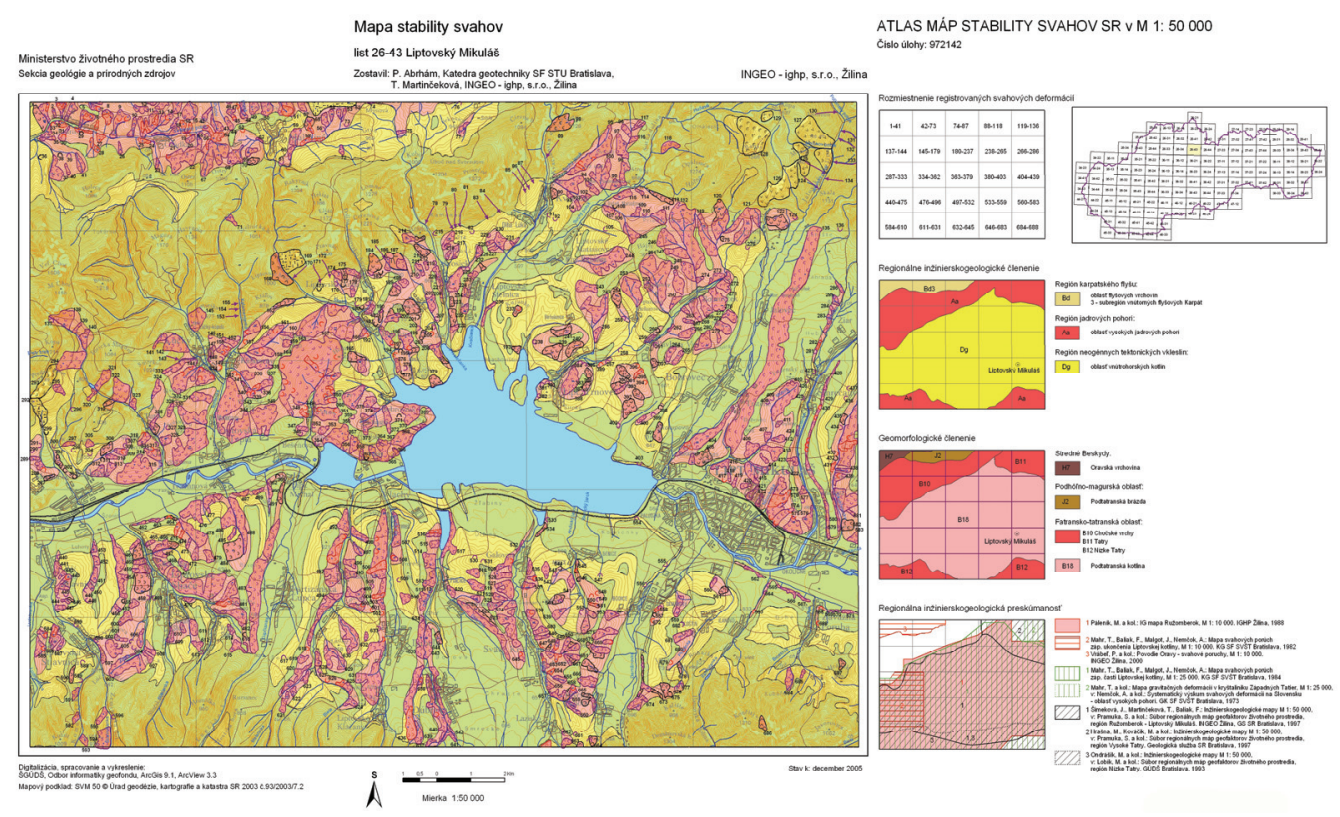

Fig. 3. Map of slope stability (map sheet 26-43 Liptovský Mikuláš [5])

\section{CONCLUSION}

Geological factors are very important part of the environment. Various engineering activities in natural environment are fundamentally affected by geofactors. It is necessary to predict the impact of these activities (including mineral processing) on the environment also in the context of geological environment and its geofactors. All par- 
ticipants in engineering activities should be bound to protect society from damaging impacts of geobarriers and simultaneously contribute to preservation of geopotentials. The most effective tool for predicting geofactors is permanent and consistent monitoring. The purpose of the monitoring is to follow and evaluate the mechanism of origin and development of processes within the geological medium (environment), to anticipate the development trends in time and space and to propose adequate measures for abatement of negative impacts of these processes.

This research was funded by the grant No. 1/0944/11 VEGA Agency.

\section{REFERENCES}

[1] Act on Environment, No. 17/1992 (http://jaspi.justice.gov.sk)

[2] BALIAK F., Mapy svahových porúch ako pomôcka pri znaleckej činnosti, Almanách znalca, Roč. 8, č. 3/2009, SvF STU Bratislava, 2009, 24-27.

[3] BALIAK F., MALGOT J., Geologické faktory urbanistickej výstavby, [in:] K. KATtoš (ed.), Infraštrukturálne a technické hl'adiská v priestorovom plánovaní, ROAD, Bratislava, 2000, 21-53.

[4] Klukanová A., SpišÁK Z., Petro L., KovÁČIK M., Smernica na zostavenie inžinierskogeologických máp geofaktorov životného prostredia v mierke 1:50.000, Manuscriptum, archív ŠGúDS̆, Bratislava, 1995, p. 20.

[5] Malgot J., Baliak F., Abrahm P., SolČIAnSky R., KopeckÝ M., Mapa stability svahov, list 26-43 Liptovský Mikuláš, [in:] J. Šimeková, T. Martinčeková, P. Abrahám, T. Gejdoš, A. Grenčíkova, D. Grman, M. Hrašna, D. Jadroň, A. Záthurecký, E. Kotrčová, P. Liščák, J. Malgot, M. Masný, M. Mokrá, L. Petro, E. Polaščinová, R. Solčiansky, M. Kopecký, E. Žabková, D. Wanieková, Atlas máp stability svahov SR v $M=1: 50000$, INGEO-IGHP, Žilina, 2006

[6] Matula M., Geológia v územnom plánovani a výstavbe, Vydavatel'stvo Príroda a.s., Bratislava, 1995, p. 224.

[7] Petro L., Frankovská J., Matys M., Wagner P., Bednárik M., Grünner K., Holzer R., Hrašna M., Hulla J., JÁNOVÁ V., KovÁČIK M., KovÁČIKOVÁ M., LišČÁK P., MODLITBA I., ONDRÁŠIK M., ONDRÁŠIK R., PAUDITŠ P., SLIVOVSKÝ M., VLČKO J., Inžinierskogeologický a geotechnický terminologický slovník, Štátny geologický ústav Dionýza Štúra, Bratislava, 2008, p. 465.

[8] Pramuka S., Cicmanová S., Čurlík J., Klukanová A., Lanc J., LuČIvjanský L., Nagy A., Olešák S., ŠEFČ́́K P., VOJEK R., Mapa významných geologických faktorov severovýchodnej časti okresu Levice v mierke 1:50000, Záverečná správa geologickej úlohy, Geofond ŠGÚDŠ, Bratislava, 2006, p. 58. 